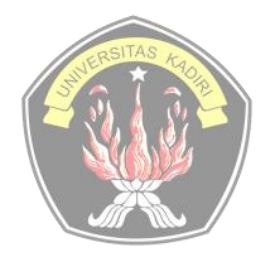

Tersedia online di

\title{
Pengaruh Customer Relationship Marketing dan Kualitas Layanan Terhadap Kepuasan : Studi Konsumen McDonald's Kediri
}

\author{
Nur Laely ${ }^{1}$, Djunaedi ${ }^{2}$, Dea Rosita ${ }^{3}$ \\ ${ }^{12} 2$ Fakultas Ekonomi, Universitas Kadiri
}

email:nurlaely@unik-kediri.ac.id;djunaedi@unik-kediri.ac.id; dearositta48@gmail.com

\section{Artikel History:}

Artikel masuk : 29-08-2020

Artikel revisi : 17-09-2020

Artikel diterima : 29-09-2020

\section{Keywords:}

parsial, simultan, kepuasan

\begin{abstract}
ABSTRAK
McDonald's merupakan salah satu restoran cepat saji yang memiliki cabang di Kota Kediri. Restoran tersebut saat ini memiliki kompetitor yang dapat memberikan dampak penurunan kepuasan bagi para pelanggannya. Oleh sebab itu, dari penelitian yang dilakukan bertujuan untuk mengetahui pengaruh parsial dan pengaruh simultan dengan penggunaan variabel bebas Customer Relatioship Management dan Kualitas Layanan serta variabel terikat Kepuasan Pelanggan. Sampel yang digunakan pada penelitian ini sejumlah 93 responden menggunakan formula Slovin. Berdasarkan hasil penelitian, karakteristik responden dominan pada usia $<20$ tahun berjenis kelamin perempuan, tingkat pelajar/mahasiswa yang pendapatannya $<1$ juta pada pendidikan SMA sederajat. Secara parsial dan simultan Customer Relatioship Management dan Kualitas Layanan, masing - masing memiliki pengaruh signifikan terhadap Kepuasan Pelanggan.
\end{abstract}




\section{PENDAHULUAN}

Perkembangan usaha pada abad 20 ini sangat pesat, yang mampu memberikan pengaruh cukup besar terhadap dampak perekonomian yang ditimbulkan. Dampak meningkatnya perekonomian didukung informasi dari Bank Indonesia pada tahun 2019 dengan perkiraan pertumbuhan ekonomi sebesar 5\% sampai dengan 5,4\% pada tahun 2019 (Badan Pusat Statistik, 2019). Selain itu, adanya dukungan kemudahan dalam bidang investasi dan konsumsi permintaan lokal pada aktivitas daya beli masyarakat.

Tabel 1. Proyeksi Pertumbuhan Perekonomian Negara Indonesia Tahun 2019

\begin{tabular}{|l|c|}
\hline \multicolumn{1}{|c|}{ Indikator } & $2019(\%)$ \\
\hline Pertumbuhan perekonomian $^{1)}$ & $5,0-5,4$ \\
\hline Pertumbuhan perekonomian $^{2)}$ & 5,2 \\
\hline Pertumbuhan perekonomian $^{3)}$ & 5,2 \\
\hline
\end{tabular}

Sumber :

1) Publikasi Laporan Perekonomian Indonesia 2018, Bank Indonesia (Indonesia, 2018)

2) Publikasi World Economic Outlook Database April 2019, International Monetary Fund (IMF) (Fund, 2019)

3) Publikasi Asian Development Outlook (ADO) 2019, Asian Development Bank (ADB) (Bank, 2019)

Dalam hal ini, usaha - usaha yang berdiri di Indonesia sudah memiliki kemudahan yang terkait dengan aturan investasi dan mentarget konsumsi masyarakat untuk meningkatkan perekonomian negara. Selain itu, masyarakat modern dituntut untuk lebih cepat dalam melakukan aktvitas baik dalam pekerjaan untuk mencapai target yang diharapkan perusahaan.Aktivitas yang serba cepat ini, akan menuntut keinginan masyarakat dalam hal konsumsi. Konsumsi yang diharapkan, tersedianya produk makanan dan minuman yang dapat tersaji secara cepat untuk dinikmati sendiri, atau bersama rekan - rekan kerja.Produk makanan siap saji yang dapat memenuhi kebutuhan masyarakat dapat ditemui diberbagai tempat, seperti mall, kedai, food court. Perkembangan gaya hidup ini, digunakan oleh restoran McDonald's untuk menangkap peluang dan memanfaatkan momen berharga terkait makanan dan minuman cepat saji untuk memenuhi selera masyarakat Indonesia (Widjoyo, Rumambi, \& Kunto, 2013). McDonald's adalah restoran yang berdiri pada tahun 1940 yang dimiliki oleh Dick dan Mac McDonald, kemudian dibeli dan diperluas cabangnya oleh Ray Kroc. Persaingan makanan cepat saji semakin ketat, dengan munculnya berbagai brand kompetitor. Terkait dengan makanan cepat saji, diperlukan manajemen hubungan pelanggan atau dikenal dengan nama Customer Relationship Management. Fungsinya sebagai membangun dan mempertahankan 
hubungan produsen dengan pelanggan dalam kegiatan konsumsi produk baik dalam bentuk barang atau jasa. Seperti penelitian yang dilakukan oleh (Panjaitan \& Djunaedi, 2017), sumber daya manusia yang digunakan dapat memberikan hubungan yang baik bagi pelanggan. Dari hal tersebut, Customer Relationship Management memberikan pengaruh pada kepuasan pelanggan dibidang Perbankan.Customer Relationship Management akan berkaitan dengan Kualitas Layanan untuk mempererat hubungan produsen dengan pelanggan. Fungsi dari Kualitas Layanan sebagai cara mengetahui pengelolaan ekspetasi, bukti kualitas, menumbuhkan budaya kualitas, menciptakan kualitas otomatis dan pengembangan sistem informasi kualitas layanan (Tjiptono \& Tjiptono, 2012). Pada penelitian yang dilakukan oleh (Widjoyo et al., 2013), bahwa pelayanan yang diberikan sesuai dengan harapan pelanggan akan memberikan kepuasan pelanggan pada layanan drive thru di McDonald's Basuki Rahmat Surabaya. Dalam hal ini, sutau pelayanan sangat penting dilakukan untuk memberikan kepuasan pada pelanggan. Kemudian pada penelitian selanjutnya yaitu (Purnamasari \& Madiawati, 2014), bahwa memberikan pelayanan yang baik kepada pelanggan akan memberikan dapak positif untuk meningkatkan kepuasan pelanggan. Semakin baik pelayanan yang diberikan, pelanggan merasa puas karena bukti fisik restoran, respon pelayanan, empati yang diberikan, jaminan pelayanan dan janji yang diberikan sesuai harapan pelanggan.

Permasalahan yang timbul adalah banyaknya kompetitor sejenis akan menyebabkan penurunan kepuasan pada McDonald's jika tidak ada strategi - strategi yang dapat memberikan kepuasan bagi pelanggan. Sesuai dengan visi yang usung adalah memberikan pelayanan cepat saji terbaik didunia, mutu produk terjamin, pelayanan memuaskan, kebersihan dan keamanan produk serta senyum konsumen adalah hal penting. Kemudian, misi yang diangkat adalah perusahaan terbaik bagi semua karyawan, pelayanan unggul dan perkembangan dalam brand, sistem operasional terkait inovasi dan teknologi. Restoran McDonald's Kediri rata - rata dalam sehari didatangi pengunjung sebanyak 100 pelanggan pada waktu - waktu tertentu seperi akhir pekan. Oleh sebab itu, penelitian ini memiliki tujuan untuk mengetahui pengaruh parsial dari masing - masing variabel bebas Customer Relatioship Management dan Kualitas Layanan terhadap Kepuasan Pelanggan dan untuk mengetahui pengaruh simultan Customer Relatioship Management dan Kualitas Layanan terhadap Kepuasan Pelanggan. Batasan penelitian ini adalah variabel bebas yaitu Customer Relatioship Management dan Kualitas Layanan, sedangkan variabel terikat adalah Kepuasan Pelanggan. Asumsi yang digunakan adalah tidak ada perubahan data baik penyebaran dan pengisian kuesioner oleh responden maupun jumlah sampel responden yang sudah terpilih selama observasi. Manfaat penelitian ini bagi akademik sebagai referensi pengembangan ilmu dalam bidang manajemen pemasaran, bagi peneliti 
selanjutnya sebagai referensi acuan penelitian dan bagi perusahaan restoran sebagai bahan mencapai visi dan misi agar semakin baik.

\section{TINJAUAN PUSTAKA}

\section{Customer Relationship Management}

Customer Relationship Management yaitu proses yang mampu membangun dan mempertahankan hubungan produsen dengan konsumen agar menciptakan keuntungan berupa produk yang bernilai bagi konsumen dan membuat konsumen merasa puas (Philip \& Armstrong, 2010). Selain itu, digunakan produsen untuk membina relasi kepada pelanggan dengan tujuan memelihara kesetiaan dan komitmen pelanggan untuk tetap menggunakan produk perusahaan yang bersangkutan (Komari, Laely, \& Panjaitan, 2017). Terdapat 3 faktor pendorong suksesnya hubungan antara pemasar dengan pelanggan yaitu:

a. Customer value: rasio perbedaan antara manfaat yang diterima dengan sumber daya yang digunakan untuk mendapatkan manfaat tersebut.

b. Customer satisfaction: persepsi seseorang terhadap kinerja suatu produk atau jasa hubungan dengan harapannya.

c. Customer retention: merupakan tujuan dari penawaran produk yang bernilai secara terusmenerus dan lebih dibandingkan dengan pesaing lainnya, sehingga konsumen sangat puas dan tetap loyal terhadap produk dan merek perusahaan.

Menurut (Nurlaely, Sularso, \& Panjaitan, 2019), agar pelaksanaan program Customer Relationship Management (CRM) menjadi sukses, terdapat beberapa hal yang harus diperhatikan, yaitu:

a. CRM tidak hanya sekedar pengolahan data, namun merupakan bagian dari teknologi.

b. Monitor dan perhatian undang-undang privasi dan perlindungan data di negara dimana program CRM digunakan.

c. Keefektifan program CRM dimulai dari database. Database yang baik akan menguntungkan perusahaan, sedangkan database yang buruk merupakan pemborosan bagi perusahaan.

d. Informasi dan penghargaan yang diberikan hendaknya kepada konsumen yang relevan.

Program Customer Relationship Management memerlukan komunikasi antara perusahaan dengan pihak-pihak terkait yang mendukung perusahaan dalam menjalankan usahanya. Komunikasi yang terjalin bukanlah monolog atau satu arah, namun diperlukan adanya dialog yaitu melibatkan dua pihak atau lebih dalam proses saling memberi dan menerima informasi. Selain itu, perusahaan dewasa ini harus melakukan direct communication Pengaruh Customer Relationship..... 
atau komunikasi secara langsung. Hal ini diperlukan mengingat semakin kompleksnya kebutuhan, keinginan dan standar kualitas yang diinginkan konsumen terhadap produk-produk yang dibutuhkan.

Menurut (Lovelock, 2012) menyatakan bahwa, aplikasi secara umum Customer Relationship Management adalah pengumpulan data, analisis data, otomatisasi tenaga penjualan, otomatisasi pemasaran dan otomatisasi pusat panggilan. Data pelanggan amat penting dengan melakukan analisis data akan didapat kebutuhan spesifik pelanggan sehingga memudahkan perusahaan memberi layanan dan memenuhi kebutuhan mereka. Otomatisasi akan memudahkan perusahaan memperoleh simpati, tanggapan dan respon positif pelanggan dan pada akhirnya meningkatkan minat beli mereka.

\section{Kualitas Pelayanan}

Kualitas pelayanan memiliki lima dimensi yang dijadikan sebagai pedoman oleh pelanggan didalam melakukan penilaian terhadap jasa yang digunakan. Lima dimensi tersebut antara lain (Zeithaml, 2010) :

a. Tangible adalah penampilan fisik, peralatan dan orang yang bekerja.

b. Empathy adalah kepedulian dengan memberikan perhatian secara pribadi bagi pelanggan.

c. Reliability adalah kemampuan dalam melaksanakan jasa sesuai dengan yang dijanjikan dengan tepat dan terpercaya.

d. Responsiveness adalah kemauan untuk membantu pelanggan dan memberikan jasa secara tepat.

e. Assurance adalah pengetahuan dan kesopanan karyawan serta mampu memberikan kepercayaan dan keyakinan.

Lima dimensi digunakan dalam menilai kualitas pelayanan jasa, penggunaan strategi strategi sangat perlu dilakukan. Menurut (Vina Mandasari, 2012), faktor yang digunakan untuk meningkatkan kualitas pelayanan antara lain, cara melakukan identifikasi determinasi utama kualitas pelayanan, cara mengelola ekspetasi pelanggan, mengelola bukti kualitas pelayanan, mendidik konsumen tentang pelayanan, menumbuhkan budaya kualitas, menciptakan automating quality, menindaklanjuti pelayanan dan melakukan pengembangan sistem informasi kualitas pelayanan (Tjiptono \& Tjiptono, 2012). Kemudian, yang menjadi penghambat dari kualitas pelayanan antara lain, terjadinya produksi dan konsumsi secara bersama- sama, adanya keterlibatan tenaga kerja yang tinggi, adanya janji - jani yang berlebihan pada produk - produk yang menawarkan jasanya,adanya cara melakukan pelanggan 
secara sama, dilakukan perluasan layanan secara berlebihan, visi bisnis dengan jangkauan yang pendek (Kelana Putera \& Wahyono, 2018).

\section{Kepuasan Pelanggan}

Kepuasan pelanggan adalah perasaan pelanggan dalam perbandingan persepsi sesuai harapan atau diluar harapan. Jika apa yang digunakan memiliki nilai yang lebih dari harapan akan menimbulkan perasaan senang dan sebaliknya. Jika apa yang digunakan memiliki nilai kurang dari yang diharapkan akan menimbulkan perasaan kecewa (Hill \& Alexander, 2017). Kepuasan dapat dirasakan setelah produk barang atau jasa sudah digunakan. Terkait dengan layanan yang diberikan kepada pelanggan, pemberi layanan harus bersikap sesuai dengan apa yang diharapkan pelanggan. Menurut (Zeithaml, 2010), dalam kepuasan pelanggan akan berkaitan erat dengan layanan yang diberikan. Semakin baik layanan yang diberikan kepada pelanggan, maka akan semakin tinggi nilai kepuasan yang dapat diungkapkan oleh pelanggan.

\section{Hubungan Antar Variabel Penelitian}

\section{Hubungan Customer Relationship Management dengan Kepuasan Pelanggan}

Penelitian yang dilakukan oleh (Brahmasari \& Panjaitan, 2016) membuktikan adanya hubungan Customer Relationship Management dengan Kepuasan Pelanggan. Hasil penelitian tersebut memberikan bukti indikator pada Customer Relationship Management mampu memberikan pengaruh terhadap kepuasan pasien yang berada di rumah sakit militer II. Pada penelitian selanjutnya yaitu (Panjaitan \& Djunaedi, 2017), dinyatakan Customer Relationship Management mampu memberikan pengaruh terhadap kepuasan pelanggan dengan capaian pengelolaan sumber daya yang baik dan dapat memenuhi kebutuhan pelanggan.Kemudian hubungan antar variabel tersebut didukung dengan adanya peningkatan kepuasan pelanggan jika penerapan Customer Relationship Management dilakukan dengan baik (Binsar Kristian P. \& Panjaitan, 2014).

\section{Hubungan Kualitas Layanan dengan Kepuasan Pelanggan}

Kualitas layanan memiliki hubungan dengan kepuasan pelanggan didukung dengan penelitian yang dilakukan oleh (Panjaitan \& Djunaedi, 2017), dengan hasil kualitas layanan yang baik dapat meningkatkan kepuasan pelanggan, dengan memberikan tolak ukur sejauh mana layanan dapat memberikan harapan bagi pelanggan, kebutuhan pelanggan dan keinginan pelanggan secara akurat. Kualitas pelayanan mampu memberikan kepuasan kepada pelanggan dengan adanya jaminan terkait peningkatan sumber daya manusia, cepat tanggap terhadap keinginan konsumen dan fasilitas yang menjamin kepuasan pelanggan 
(Putranto, Utami, \& Nurbambang, 2019). Kualitas layanan terkait dengan cepat tanggap menerima keluhan konsumen, kesediaan karyawan membantu konsumen dan kecepatan dalam menyelesaikan masalah akan mampu meningkatkan kepuasan pelanggan (Hariyono, Laely, \& Prastiti, 2019). Terkait dengan teknologi elektronik dalam melakukan hubungan kualitas layanan dengan kepuasan pelanggan, penelitian yang dilakukan oleh (Putra, Safi'i, \& Ruhamak, 2017), E-Service Quality memberikan pengaruh terhadap E-Loyality melalui E-Satisfaction didukung dengan perkembangan teknologi dalam layanan di aplikasi, sehingga memunculkan rasa puas nasabah dan mempu memberikan loyalitas kepada pihak bank. Pengaruh kualitas layanan terhadap kepuasan pelanggan memiliki hubungan positif didukung dengan penelitian yang dilakukan oleh (W, Utami, \& Rochani, 2018), layanan dikategorikan baik pada Alfamart yang dapat memberikan kepuasan bagi pelanggan.

\section{Kerangka Proses Berpikir}

Penelitian ini memiliki kerangka konseptual yang digunakan untuk proses berpikir dalam penyusunan penelitian. Teori pendukung penelitian ini, yaitu :

a. Customer Relationship Management

b. Kualitas Layanan

c. Kepuasan Pelanggan

Teori pendukung tersebut, digambarkan sebagai berikut :

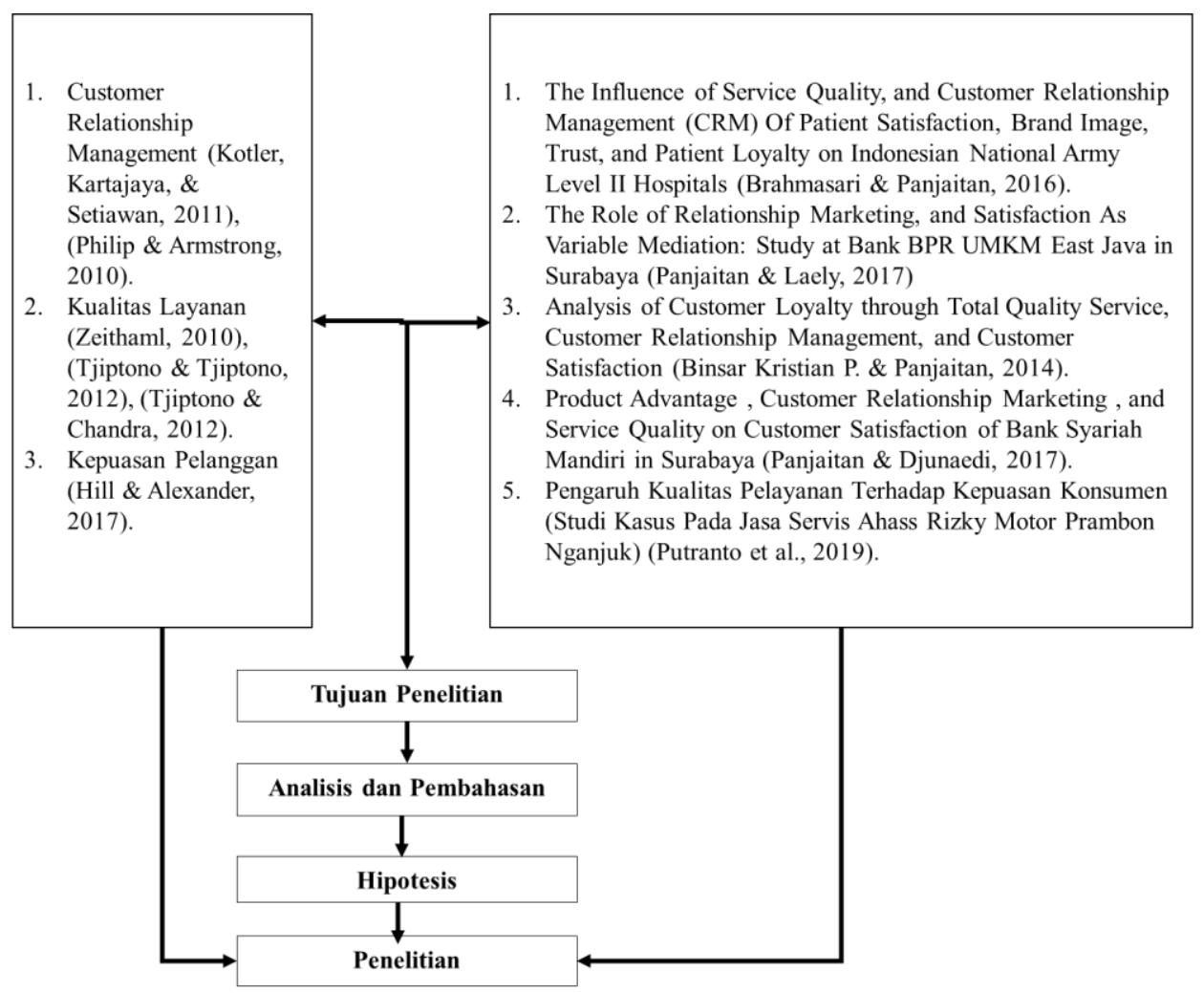

Gambar 1. Kerangka Proses Berpikir

\section{Kerangka Konseptual}

Pengaruh Customer Relationship.... 
Penggunaan kerangka konseptual adalah bagian dari mekanisme penelitian. Penelitian ini, menggunakan klasifikasi variabel sebagai berikut :

a. Variabel independen yaitu : Customer Relationship Management (X1) dan Kualitas Layanan (X2).

b. Variabel dependen yaitu : Kepuasan Pelanggan (Y).

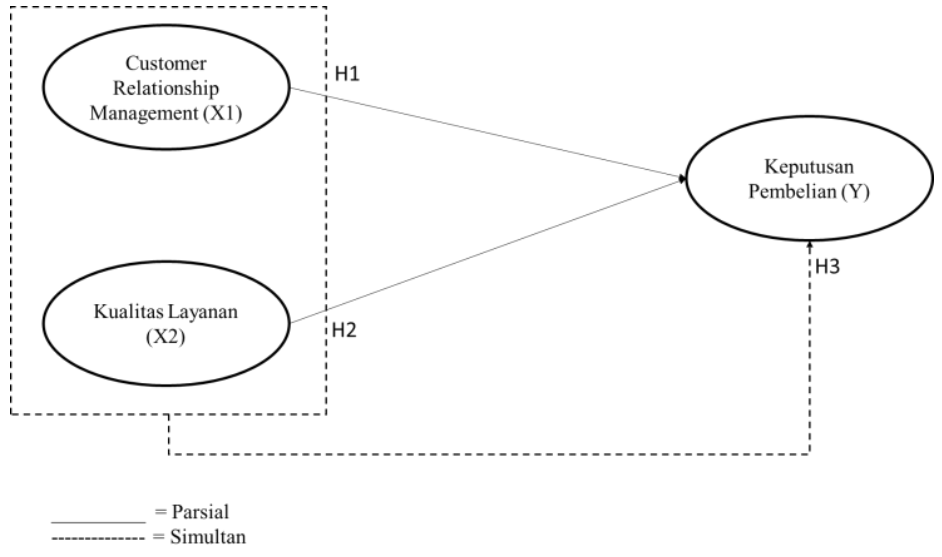

Gambar 2. Kerangka Konsep Penelitian

Kerangka pemikiran yang digunakan menunjukkan bahwa variabel Customer Relationship Management (X1) ditunjukkan H1 dan Kualitas Layanan (X2) ditunjukkan H2, masing masing memiliki pengaruh secara parsial terhadap Kepuasan Pelanggan (Y) pada McDonalds Kediri.. Pada Customer Relationship Management dan Kualitas Layanan ditunjukkan H3 memiliki pengaruh secara bersama - sama terhadap Kepuasan Pelanggan (Y) pada McDonalds Kediri.

\section{Hipotesis Penelitian}

Berdasarkan pendahuluan, tinjauan pustaka dan kerangka konseptual. Hipotesis yang diajukan dalam penelitian ini adalah :

a. Customer Relationship Management berpengaruh signifikan terhadap Kepuasan Pelanggan di McDonalds Kediri.

b. Kualitas Layanan berpengaruh signifikan terhadap Kepuasan Pelanggan di McDonalds Kediri.

Customer Relationship Management dan Kualitas Layanan berpengaruh signifikan terhadap Kepuasan Pelanggan di McDonalds Kediri.

\section{METODE PENELITIAN}

Pengaruh Customer Relationship.... 


\section{Populasi dan Sampel}

Populasi adalah wilayah yang digeneralisasi dengan subyek atau obyek berkarakteristik tertentu untuk dipelajari dan diambil kesimpulannya (Sugiyono, 2014). Populasi dalam penelitian ini adalah pelanggan yang sudah pernah melakukan pembelian menu sebanyak satu kali pada McDonald's Kediri yang berjumlah 1430 pelanggan selama periode penelitian dimulai sejak 12 Januari sampai dengan 12 Maret 2020. Sedangkan sampel penelitian adalah bagian dari subyek atau obyek berkarakteristik yang dimiliki oleh populasi (Sugiyono, 2014). Pada penelitian ini, jumlah sampel penelitian ditentukan menggunakan formula Slovin sebagai berikut (Hidayat, 2017) :

$$
n=\frac{N}{1+N e^{2}}
$$

Keterangan :

$\mathrm{n}=$ jumlah sampel penelitian

$\mathrm{N}=$ jumlah populasi

$\mathrm{e}=$ margin of error $(10 \%)$

Maka, besar sampel yang digunakan untuk melakukan penelitian ini adalah sebagai berikut:

$$
n=\frac{1430}{1+\left(1430 \times\left(0,1^{2}\right)\right)}=93,4 \approx 93 \text { responden }
$$

\section{Metode Pengambilan Sampel}

Penelitian ini melakukan pengambilan sampel dengan metode pemberian peluang yang sama bagi anggota populasi yang telah terpilih menjadi anggota sampel yang disebut dengan probability sampling. Kemudian melakukan penarikan populasi dengan cara tertentu. Maka,tiap anggota dari populasi memiliki peluang sama untuk dipilih secara acak tanpa melakukan perhatian khusus terkait strata dalam populasi (Sugiyono, 2014).

\section{Subjek dan Objek Penelitian}

Subjek penelitian ini adalah McDonald's Kediri yang digunakan untuk penelitian mencari informasi tentang tentang data yang mendukung topik penelitian (Sugiyono, 2014). Sedangkan obyek penelitian adalah terkait Kepuasan pelanggan dengan topik Pengaruh Customer Relationship Management dan Kualitas Layanan Terhadap Kepuasan : Studi Konsumen McDonald's Kediri.

\section{Variabel Operasional}


Dalam penelitian ini, penggunaan variabel adalah variabel terikat dan variabel bebas. Pada variabel terikat adalah variabel yang memiliki konsekuensi, keluaran yang mampu memberikan tolak ukur dan sedang dipelajari pada percobaan. Oleh sebab itu, dapat memberikan respon terhadap variabel bebas, karena variabel terikat tergantung dengan variabel bebas (Heryana, 2015). Variabel bebas adalah variabel yang memiliki perubahan tanpa ada pengaruh oleh variabel lain selama percobaan. Dalam hal ini, variabel bebas dikendalikan oleh eksperiman, sedangkan nilai pada variabel terikat hanya mampu berubah ketika berfungsu sebagai respon terhadap variabel bebas (Gürbilek, 2013). Variabel terikat pada penelitian ini adalah kepuasan pelanggan. Sedangkan pada variabel bebas yang digunakan adalah Customer Relationship Management dan Kualitas Pelayanan.

Terkait dengan cara pengukuran untuk memberikan pernyataan dari tanggapan yang diberikan responden menggunakan skala likert (Budiaji, 2013).Skala likert tersebut adalah jawatban setiap item pertanyaan dari tiap indikator. Dalam skala likert yang digunakan, skor minimum adalah angka 1 dengan sikap responden sangat tidak setuju sampai dengan angka 5 dengan sikap responden sangat setuju.

Penggunakan indikator pada setiap variabel digunakan untuk mengetahui pengukuran variabel bebas dan variabel terikat yang mampu memberikan hasil penelitian sesuai dengan tujuan yang ingin dicapai (Gürbilek, 2013).

Tabel 2 Variabel Operasional

\begin{tabular}{|c|c|c|c|c|}
\hline Konsep & Variabel & Indikator & Skala & $\begin{array}{c}\text { Skor }=\text { Sikap } \\
\text { Responden }\end{array}$ \\
\hline \multirow{15}{*}{$\begin{array}{l}\text { Pengaruh } \\
\text { Customer } \\
\text { Relationshi } \\
p \\
\text { Managemen } \\
t \text { dan } \\
\text { Kualitas } \\
\text { Layanan } \\
\text { Terhadap } \\
\text { Kepuasan : } \\
\text { Studi } \\
\text { Pelanggan } \\
\text { McDonald's } \\
\text { Kediri }\end{array}$} & Customer & 1. Pemasaran Individu & \multirow[t]{5}{*}{ Likert } & 1= Sangat Tidak Setuju \\
\hline & Relationsh & 2. Pemasaran Berkelanjutan & & $2=$ Tidak Setuju \\
\hline & & 3. Program Kemitraan & & $3=$ Netral \\
\hline & Managem & & & $4=$ Setuju \\
\hline & ent $\left(\mathrm{X}_{1}\right)$ & & & $5=$ Sangat Setuju \\
\hline & Kualitas & 1. Tangible & \multirow[t]{5}{*}{ Likert } & 1= Sangat Tidak Setuju \\
\hline & \multirow{4}{*}{$\begin{array}{l}\text { Pelayanan } \\
\quad\left(\mathrm{X}_{2}\right)\end{array}$} & 2. Reliability & & $2=$ Tidak Setuju \\
\hline & & 3. Responsiveness & & $3=$ Netral \\
\hline & & 4. Assurance & & $4=$ Setuju \\
\hline & & 5. Emphaty & & $5=$ Sangat Setuju \\
\hline & \multirow{5}{*}{$\begin{array}{c}\text { Kepuasan } \\
\text { (Y) }\end{array}$} & 1. Pilihan Produk & \multirow[t]{5}{*}{ Likert } & 1= Sangat Tidak Setuju \\
\hline & & 2. Pilihan Merk & & $2=$ Tidak Setuju \\
\hline & & 3. Pilihan Distribusi & & $3=$ Netral \\
\hline & & 4. Pilihan Waktu Pembelian & & $4=$ Setuju \\
\hline & & & & $5=$ Sangat Setuju \\
\hline
\end{tabular}

(Sumber :Olah data,2020) 


\section{Jenis dan Sumber Data}

Penggunaan data dalam penelitian ini adalah data primer dan data sekunder. Data primer yaitu data yang berbentuk softfile dan hardfile yang diperoleh melalui observasi. Data primer yang dimaksudkan adalah bentuk wawancara dan penyebaran kuesioner kepada responden yang telah terpilih dan menjadi sampel penelitian (Maksum, 2012). Data sekunder adalah data yang sudah tersedia untuk mendukung penelitian. Data tersebut didapatkan melalui literasi, penelitian terdahulu, jurnal penelitian, maupun e-book yang memiliki reputasi (Maksum, 2012).

Tabel 3 Jenis dan Sumber Data

\begin{tabular}{|c|c|c|c|c|}
\hline No. & Nama data & Jenis data & Sumber data & Tempat \\
\hline 1 & $\begin{array}{l}\text { Penyebaran } \\
\text { kuesioner }\end{array}$ & Data primer & responden & McDonald's Kediri \\
\hline 2 & Wawancara & Data primer & responden & McDonald's Kediri \\
\hline 3 & $\begin{array}{l}\text { Kajian } \\
\text { Pustaka }\end{array}$ & Sekunder & $\begin{array}{lr}\text { literasi, } & \text { penelitian } \\
\text { terdahulu, } & \text { jurnal } \\
\text { penelitian, maupun e-book }\end{array}$ & $\begin{array}{l}\text { Internet, Toko Buku, Open } \\
\text { System Journal, } \\
\text { Perpustakaan }\end{array}$ \\
\hline
\end{tabular}

(Sumber : Olah data,2020)

\section{Teknik Pengumpulan Data}

Kegiatan yang dilakukan pada teknik pengumpulan data adalah observasi, wawancara, penyebaran kuesioner dan studi pustaka. Pada observasi yaitu peneliti melakukan penelitian secara langsung pada obyek yang diteliti dengan cara pengumpulan dan pencatatan perilaku orang, benda atau kejadian yang dilakukan tanpa ada komunikasi dengan individu (Agusta, 2014). Kemudian kegiatan wawancara dilakukan ketika peneliti mengajukan pertanyaan kepada responden dalam bentuk tertulis atau lisan. Pada kuesioner yang digunakan berfungsi sebagai pengumpulan data yang dapat memberikan pernyataan tertulis untuk dijawab responden. Terkait dengan penggunaan studi pustaka diguankan sebagai pendukung penelitian yang dapat diperoleh dari Internet, Toko Buku, Open System Journal, Perpustakaan

\section{Teknik Analisis Data}

Teknik analisis data yang digunakan sebagai berikut (Whidmurni, 2017) :

1. Uji Validitas digunakan untuk menguji kevalidan tiap pernyataan pada masing - masing indikator. Cara yang digunakan yaitu mengkorelasikan skor yang diperoleh dari jawaban kuesioner dari skor total masing - masing indikator. Pengambilan keputusan dengan nilai $\mathrm{R}_{\text {hitung }}>\mathrm{R}_{\text {tabel }}$ dinyatakan valid (Yusup, 2018).

2. Uji Reliabilitas digunakan untuk mengukur tingkat kereliabelan dari jumlah indikator pada setiap variabel bebas dan variabel terikat. Penggunaan nilai pada uji reliabilitas menggunakan tingkat interval dan dengan kriteria sebagai berikut (Andriani, 2017). 
Tabel 4. Interval dan Kriteria Cronbach Alpha

\begin{tabular}{|c|c|}
\hline Interval & Kriteria \\
\hline$<0,200$ & Sangat rendah \\
\hline $0,200-0,399$ & Rendah \\
\hline $0,400-0,599$ & Cukup \\
\hline $0,600-0,799$ & Tinggi \\
\hline $0,800-1,000$ & Sangat tinggi \\
\hline
\end{tabular}

(Sumber : (Andriani, 2017))

3. Uji Asumsi Klasik

Penggunaan uji asumsi klasik digunakan untuk mendapatkan estimasi linier terbaik (Damanik \& Wibowo, 2018), antara lain :

a. Uji Normalitas dengan nilai signifikansi > 0,05 dinyatakan data berdistribusi normal menggunakan Kolmogorov-Smirnov Test.

b. Uji Autokorelasi menggunakaan nilai Durbin Watson, jika nilai berada diantara 1,55 sampai dengan 2,46 , dinyatakan data tidak terjadi masalah autokorelasi.

c. Uji Multikolinieritas dengan nilai VIF diantara 1,00 sampai 10,000 dinyatakan data tidak terjadi multikolinieritas.

d. Uji Heterokesdastisitas dengan melihat titik - titik yang menyebar tidak jelas dibawah angka 0 pada sumbu Y menggunakan nilai prediksi variabel bebas yaitu ZPRED dengan residual SRESID.

e. Uji Linieritas dengan nilai Deviation from Linearity Sig. > 0,05 dinyatakan ada hubungan linier antara variabel bebas dengan variabel terikat.

\section{Uji Regresi Linier Berganda}

Menurut (Tumbuan, Mandey, \& Kakasih, 2014), persamaan regresi linier berganda sebagai berikut :

$$
Y=a+b_{n} X_{k}+b_{n} X_{k}
$$

Keterangan :

Y : nilai prediksi dari $\mathrm{Y}$

$\alpha \quad$ : nilai konstanta

$b_{n} \quad$ : koefisien determinasi

$\mathrm{X}_{\mathrm{k}}$ : variabel independen

5. Uji T

Uji T (parsial) untuk melihat sejauh mana pengaruh secara sendiri-sendiri pada variabel $(\mathrm{X})$ terhadap variabel (Y), dengan penerimaan hipotesis yaitu :

$\mathrm{H}_{0}$ ditolak jika sig. $>0,05$ atau $\mathrm{T}_{\text {tabel }}>\mathrm{T}_{\text {hitung }}$ 
$\mathrm{H}_{\mathrm{a}}$ diterima jika sig. $<0,05$ atau $\mathrm{T}_{\text {hitung }}>\mathrm{T}_{\text {tabel }}$

6. Uji F

Uji $\mathrm{F}$ digunakan untuk mengetahui tingkat pengaruh variabel bebas (X) secara simultan terhadap variabel terikat $(\mathrm{Y})$ menggunakan rumus :

Df1 $=\mathrm{k}-1=$ variabel bebas $-1=n$

Df2 $=\mathrm{n}-\mathrm{k}=$ jumlah responden - variabel bebas $=n$

Jadi, df1 dan df2 adalah $n$ df1; $n$ df $2=n \rightarrow$ Ftabel.

Cara membandingkan nilai $\mathrm{F}_{\text {hitung }}$ dengan $\mathrm{F}_{\text {tabel }}$ dengan ketentuan sebagai berikut:

a. Jika Sig $<0,05$ dan $\mathrm{F}_{\text {hitung }}>\mathrm{F}_{\text {tabel }}$, maka $\mathrm{H}_{0}$ ditolak dan $\mathrm{H}_{\mathrm{a}}$ diterima. Artinya secara simultan variabel bebas $(\mathrm{X})$ berpengaruh signifikan terhadap variabel terikat (Y).

b. Jika Sig $>0,05$ dan $\mathrm{F}_{\text {hitung }}<\mathrm{F}_{\text {tabel}}$, maka $\mathrm{H}_{0}$ diterima $\mathrm{H}_{\mathrm{a}}$ ditolak. Artinya secara simultan variabel bebas $(\mathrm{X})$ tidak ada pengaruh signifikan terhadap variabel terikat $(\mathrm{Y})$.

7. Koefisien Determinasi

Nilai koefisien determinasi untuk mengetahui seberapa besar penjelasan pada penelitian dan seberapa kecil apa yang tidak dijelaskan dengan melihat nilai R Square.

\section{Hasil Penelitian}

Hasil dari penelitian ini diawali dengan karakteristik responden terkait dengan usia, jenis kelamin, pekerjaan, pendapatan, pendidikan terakhir dari responden yang terpilih. Karakteristik responden sebagai berikut :

Tabel 5. Karakteristik Responden

\begin{tabular}{|c|l|c|c|}
\hline & \multicolumn{1}{|c|}{ Interval } & Frekuensi & Prosentase (\%) \\
\hline \multirow{5}{*}{ Usia } & $<20$ tahun & 50 & 53,8 \\
\cline { 2 - 4 } & $21-30$ tahun & 23 & 24,7 \\
\cline { 2 - 4 } & $31-40$ tahun & 20 & 21,5 \\
\hline \multirow{3}{*}{ Jenis Kelamin } & Laki - laki & 27 & 29 \\
\cline { 2 - 4 } & Perempuan & 66 & 71 \\
\hline \multirow{3}{*}{ Pendapatan } & PNS & 20 & 21,5 \\
\cline { 2 - 4 } & Pelajar/ Mahasiswa & 62 & 66,7 \\
\cline { 2 - 4 } & Lainnya & 11 & 11,8 \\
\hline \multirow{3}{*}{ Pendidikan } & $<1$ juta & 62 & 66,7 \\
\cline { 2 - 4 } & 1 s/d 3 juta & 17 & 18,3 \\
\cline { 2 - 4 } & $>3$ juta & 14 & 15,1 \\
\cline { 2 - 4 } & Sarjana & 33 & 35,5 \\
\cline { 2 - 4 } & SMA Sederajat & 50 & 53,8 \\
\cline { 2 - 4 } & SMP Sederajat & 10 & 10,8 \\
\hline
\end{tabular}

Karakteristik responden berdasarkan usia lebih dominan pada usia $<20$ tahun dengan jumlah 50 responden. Jenis kelamin yang paling dominan adalah perempuan dengan jumlah 66 responden. Pada karakteristik pekerjaan lebih dominan pada pelajar/mahasiswa dengan jumlah 62 
responden. Ditinjau dari segi pendapatan lebih dominan pada jumlah pendapatan $<1$ juta dan tingkat pendidikan lebih dominan adalah SMA sederajat.

Terkait dengan uji validitas, pengambilan keputusan mengacu pada nilai Rhitung > Rtabel, sedangkan pada uji reliabilitas mengacu pada batas interval yang digunakan adalah interval $0,400-0,599=$ cukup $;$ interval $0,600-0,799=$ tinggi $; 0,800-1,000=$ sangat tinggi. Jika nilai Cronbach alpha hitung berada pada ketiga interval tersebut, pengambilan keputusan nilai variabel dianggap reliabel.

Tabel 6. Uji Validitas dan Uji Reliabitas

\begin{tabular}{|c|c|c|c|c|c|c|}
\hline Variabel & Indikator & $\begin{array}{l}\text { Rtabel } \\
(\mathrm{N}-2)\end{array}$ & Rhitung & Keputusan & $\begin{array}{l}\text { Nilai } \\
\text { Cronbach } \\
\text { Alpha } \\
\end{array}$ & Keputusan \\
\hline \multirow{3}{*}{$\begin{array}{l}\text { Customer } \\
\text { Relationship } \\
\text { Management } \\
\text { (X1) }\end{array}$} & X11 & 0,2039 & 0,841 & Valid & \multirow[t]{3}{*}{0,742} & \multirow[t]{3}{*}{ Reliabel } \\
\hline & $\mathrm{X} 12$ & 0,2039 & 0,760 & Valid & & \\
\hline & $\mathrm{X} 13$ & 0,2039 & 0,838 & Valid & & \\
\hline \multirow{5}{*}{$\begin{array}{l}\text { Kualitas } \\
\text { Layanan (X2) }\end{array}$} & $\mathrm{X} 21$ & 0,2039 & 0,891 & Valid & \multirow[t]{5}{*}{0,917} & \multirow[t]{5}{*}{ Reliabel } \\
\hline & $\mathrm{X} 22$ & 0,2039 & 0,831 & Valid & & \\
\hline & $\mathrm{X} 23$ & 0,2039 & 0,827 & Valid & & \\
\hline & $\mathrm{X} 24$ & 0,2039 & 0,889 & Valid & & \\
\hline & $\mathrm{X} 25$ & 0,2039 & 0,897 & Valid & & \\
\hline \multirow[t]{4}{*}{ Kepuasan (Y) } & Y1 & 0,2039 & 0,765 & Valid & \multirow[t]{4}{*}{0,753} & \multirow[t]{4}{*}{ Reliabel } \\
\hline & $\mathrm{Y} 2$ & 0,2039 & 0,722 & Valid & & \\
\hline & Y3 & 0,2039 & 0,765 & Valid & & \\
\hline & $\mathrm{Y} 4$ & 0,2039 & 0,783 & Valid & & \\
\hline
\end{tabular}

Berdasakan uji validitas dengan pengambilan keputusan Rtabel yang digunakan sebesar 0,2039. Dari pengujian validitas nilai Rhitung > Rtabel, dinyatakan variabel bebas adalah Customer Relationship Management (X1) dan Kualitas Layanan (X2) dan variabel terikat adalah Kepuasan (Y) dinyatakan seluruhnya valid dan layak untuk dilakukan uji reliabilitas. Dari uji reliabilitas variabel - variabel tersebut memiliki nilai interval $0,400-1,000$ yaitu sebesar 0,742 ; 0,917 ; dan 0,753 dinyatakan seluruhnya reliabel. Pada uji asumsi klasik, beberapa uji yang digunakan sebagai berikut :

Tabel 7. Uji Asumsi Klasik

\begin{tabular}{|l|l|l|l|}
\hline $\begin{array}{l}\text { Pengujian Asumsi } \\
\text { Klasik }\end{array}$ & Tinjauan & Nilai yang dihasilkan & Keputusan \\
\hline Uji Normalitas & $\begin{array}{l}\text { nilai Asymp. } \\
\text { Sig. (2- } \\
\text { tailed) }>0,05\end{array}$ & 0,075 & $\begin{array}{l}\text { Data berdistribusi } \\
\text { normal }\end{array}$ \\
\hline Uji Autokerelasi & $\begin{array}{l}\text { Nilai durbin } \\
\text { watson }\end{array}$ & 2,106 & $\begin{array}{l}\text { Data tidak terjadi } \\
\text { autokorelasi }\end{array}$ \\
\hline
\end{tabular}




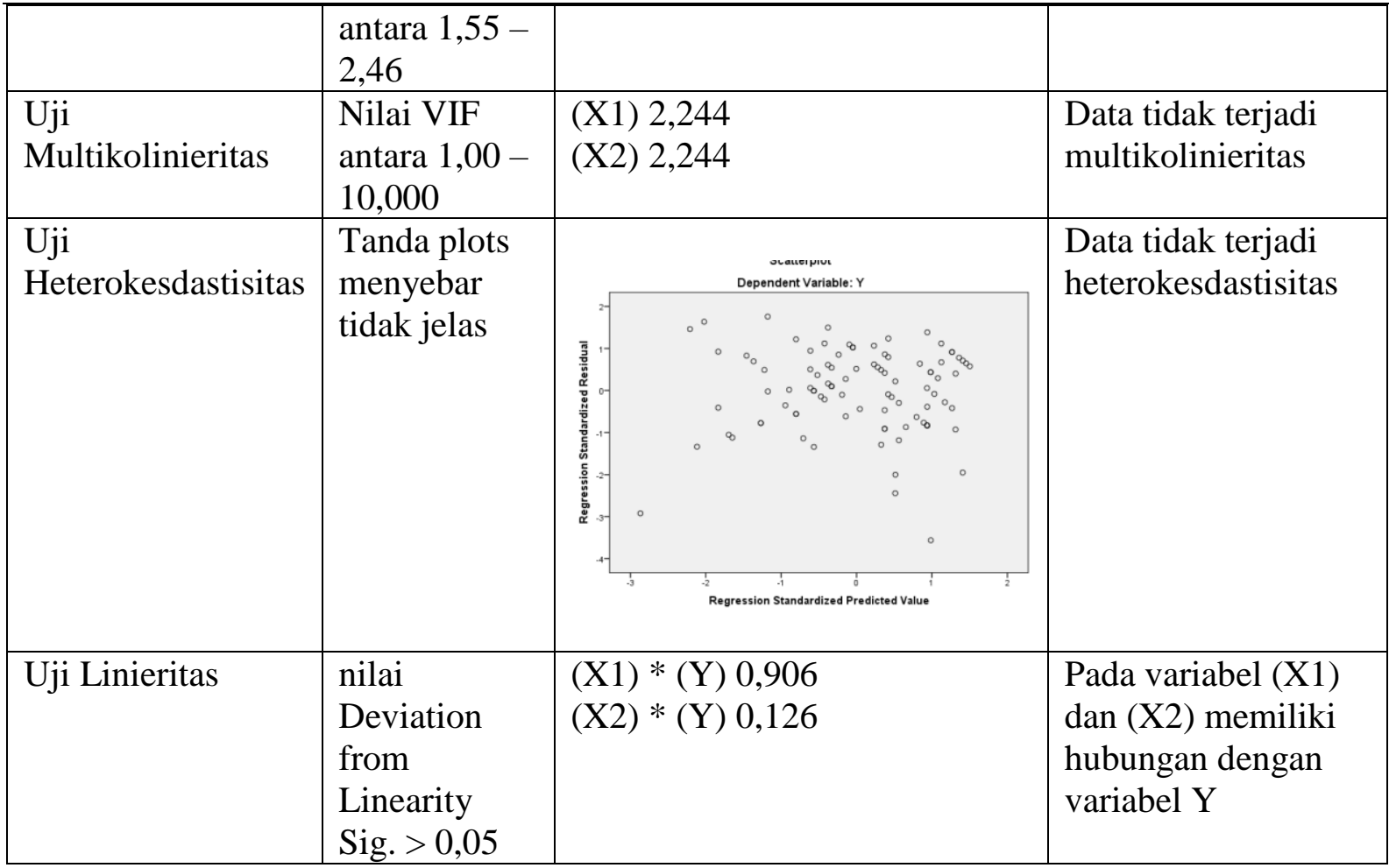

Pada uji asumsi klasik, terdiri dari uji Normalitas nilai yang didapat pada Asymp. Sig. (2-tailed) sebesar 0,075 > 0,05 dinyatakan data berdistribusi normal. Pada Uji Autokorelasi nilai DurbinWatson sebesar 2,106 dinyatakan tidak terjadi autokorelasi. Sedangkan uji Multikolinieritas dengan nilai VIF pada variabel X1 dan X2 masing - masing sebesar 0,244 dinyatakan data tidak terjadi multikolinieritas. Pada uji Heterokesdastisitas dinyatakan data tidak terjadi heterokesdastisitas karena plots menyebar tidak teratur. Sedangkan pada uji Linieritas dinyatakan variabel X1 memiliki hubungan terhadap Y dengan nilai 0,906 > 0,05 dan variabel X2 memiliiki hubungan terhadap Y dengan nilai 0,126>0,05.

Tabel 8. Regresi Linier Berganda dan Uji T

\begin{tabular}{|l|c|c|c|}
\hline \multicolumn{1}{|c|}{ Model } & B & T & Sig. \\
\hline Konstan & 4,676 & 1,783 & 0,78 \\
\hline $\begin{array}{l}\text { Customer Relationship } \\
\text { Management (X1) }\end{array}$ & 0,153 & 2,470 & 0,015 \\
\hline Kualitas Layanan (X2) & 0,455 & 7,191 & 0,000 \\
\hline
\end{tabular}

Uji regresi linier berganda didapatkan model $\mathrm{Y}=4,676+0,153 \mathrm{X} 1+0,455 \mathrm{X} 2$. Ketika variabel Customer Relationship Management dan Kualitas Layanan tidak melakukan aktivitas, kepuasan pelanggan akan bernilai konstan sebesar 4,676 satuan. Jika Customer Relationship Management melakukan aktivitas yang menghasilkan nilai sebesar 0,153 akan meningkatkan kepuasan pelanggan dengan asumsi variabel Kualitas Layanan bernilai konstan. Sedangkan pada Kualitas Layanan melakukan aktivitas yang menghasilkan nilai sebesar 0,455 akan 
meningkatkan kepuasan pelanggan dengan asumsi variabel Customer Relationship Management bernilai konstan.

Penelitian ini menggunakan Ttabel sebesar 1,98698. Untuk uji parsial, dilakukan perbandingan Thitung jika lebih besar dari Ttabel dinyatakan terdapat pengaruh dan jika asumsi nilai signifikan < 0,05 dinyatakan signifikan.. Pada Customer Relationship Management memiliki nilai Thitung sebesar 2,470> Ttabel sebesar 1,98698 dan nilai signifikan 0,015 0,05 dinyatakan memiliki pengaruh signifikan secara parsial terhadap kepuasan. Sedangkan Kualitas Layanan memiliki memiliki nilai Thitung sebesar 7,191 > Ttabel sebesar 1,98698 dan nilai signifikan $0,000<0,05$ dinyatakan memiliki pengaruh signifikan secara parsial terhadap kepuasan. Dari uji parsial variabel Customer Relationship Management dan Kualitas Layanan masing - masing memiliki pengaruh signifikan terhadap kepuasan pelanggan.

Tabel 9. Uji Simultan dan Nilai Koefisien Determinasi

\begin{tabular}{|c|c|c|}
\hline F & Sig. & R Square \\
\hline 94,537 & 0,000 & 0,678 \\
\hline
\end{tabular}

Uji simultan menggunakan asumsi Fhitung > Ftabel dengan nilai Ftabel yang digunakan sebesar 3,10 dan nilai signifikan < 0,05 dinyatakan variabel bebas secara bersama - sama memiliki pengaruh signifikan terhadap kepuasan pelanggan. Pada Customer Relationship Management dan Kualitas Layanan nilai Fhitung sebesar 94,537 > 3,10 dan nilai signifikan sebesar 0,000 < 0,05 dengan pengambilan keputusan ada pengaruh signifikan secara bersama - sama pada Customer Relationship Management dan Kualitas Layanan terhadap kepuasan pelanggan.

Nilai koefisien determinasi sebesar 0,678 atau sebesar 67,8\% yang dapat dijelaskan dari variabel Customer Relationship Management dan Kualitas Layanan terhadap kepuasan pelanggan, sedangkan sisanya sebesar $32,2 \%$ yang tidak dijelaskan pada variabel tersebut dan tidak dicantumkan pada penelitian ini.

\section{HASIL \& PEMBAHASAN}

Berdasarkan tujuan penelitian, akan dibandingkan dengan hasil penelitian dari peneliti sebelumnya. Dengan adanya Customer Relationship Management, kepuasan pelanggan dapat terpenuhi secara individual, berkelanjutan dan kemitraan. Secara individual pelanggan memiliki kepuasan dari pelayanan, pemberian produk bermutu dan keamanan pangan. Sedangkan secara berkelanjutan, dapat diberikan penawaran kartu member, adanya diskon, tingkat kebersihan sesuai dengan visi yang dicapai dan identitas senyuman sebagai hal penting bagi McDonalds. Tinjauan selanjutnya secara kemitraan, dilakukan kerjasama dengan pemasok 
bahan baku untuk memberikan kualitas, jaminan halal dan packaging yang terbuat dari bahan alami. Dari uraian Customer Relationship Management yang digunakan dapat diterima dengan baik oleh pelanggan dan dapat menimbulkan kepuasan bagi pelanggan McDonalds. Hasil tersebut searah dengan penelitian yang dilakukan oleh (Panjaitan \& Djunaedi, 2017). Penelitian yang dilakukan oleh (Panjaitan \& Djunaedi, 2017) Customer Relationship Management dapat memberikan pengaruh terhadap kepuasan pelanggan dengan memastikan tujuan yang tercapai dan dilakukan integrai kedalam rencana strategis sehingga pengelolaan sumber daya manusia dilakukan dengan baik dan memenuhi kebutuhan pelanggan.

Dengan adanya Kualitas Layanan dapat memberikan kepuasan pelanggan ditinjau dari Tangible yaitu terkait fasilitas dan pelayanan profesional, Reliability terkait dengan respon cepat dan pelayanan sesuai harapan, Responsiveness terkait dengan respon yang baik jika ada komplain dan kegiatan pelayanan kasir dengam cepat dan tepat, Assurance terkait dengan menu halal, bersih dan higienis serta penampilan pelayanan rapi dan baik serta adanya Emphaty terkait dengan pelayan cakap dalam komunikasi dan memahami kebutuhan pelanggan. Dari tinjauan tersebut, Kualitas layanan dapat memberikan pengaruh terhadap kepuasan pelanggan. Hal tersebut juga didukung dengan penelitian yang dilakukan oleh (Hariyono et al., 2019), dengan adanya Tangible, Reliability, Responsiveness, Assurance dan Emphaty dapat diketahui apa yang diharapkan pelanggan agar timbul kepuasan yang memberikan keuntungan bagi Kedai Ice Cream. Penelitian tersebut, menyatakan variabel kualitas layanan memberikan dampak positif terhadap kepuasan pelanggan.

Customer Relationship Management dan Kualitas Layanan dapat bekerja secara bersama sama dengan tingkat capaian sebesar $67,8 \%$ terhadap kepuasan pelanggan. Nilai tersebut memiliki ketepatan cukup besar yang terbentuk pada data hasil dari observasi yang sudah dilakukan. Terkait dengan hasil tersebut, secara bersama - sama dapat memberikan pengaruh terhadap kepuasan pelanggan dengan tinjauan pilihan produk beragam dan unggulan, secara branding adanya pembelian menu paket untuk memberikan daya tarik pelanggan, secara distribusi letak McDonalds yang strategis dan didukung delivery order dan secara waktu pembelian pelanggan memilih diakhir pekan serta weekday.

\section{SIMPULAN \& SARAN}

Tujuan penelitian ini, memberikan beberapa kesimpulan yaitu Customer Relationship Management memberikan pengaruh positif dan signifikan terhadap kepuasan pelanggan didukung dengan hasil penelitian oleh (Panjaitan \& Djunaedi, 2017). ; Kualitas Layaan memberikan pengaruh positif dan signifkan terhadap kepuasan pelanggan didukung dengan 
hasil penelitian (Hariyono et al., 2019) ; Customer Relationship Management dan Kualitas Layanan memberikan pengaruh positif dan signifikan secara bersama - sama terhadap kepuasan pelanggan.

\section{DAFTAR PUSTAKA}

Agusta, I. (2014). Teknik Pengumpulan dan Analisis Data Kualitatif. Jurnal Studi Komunikasi Dan Media, 02(1998), 1-11.

Andriani, D. P. (2017). Validitas dan reliabilitas skala. Universitas Brawijaya, pp. 1-39. Retrieved from http://www.ncbi.nlm.nih.gov/pubmed/15350854

Badan Pusat Statistik. (2019). Laporan Perekonomian Indonesia 2019. Laporan Perekonomian Indonesia 2019, 04(01), 1-224.

Bank, A. D. (2019). Publikasi Asian Development Outlook (ADO). Asian Development Bank.

Binsar Kristian P., F. A., \& Panjaitan, H. (2014). Analysis of Customer Loyalty through Total Quality Service, Customer Relationship Management, and Customer Satisfaction. International Journal of Evaluation and Research in Education (IJERE), 3(3), 142-151. https://doi.org/10.11591/ijere.v3i3.6191

Brahmasari, I. A., \& Panjaitan, H. (2016). The Influence of Service Quality, and Customer Relationship Management (CRM) Of Patient Satisfaction, Brand Image, Trust, and Patient Loyalty on Indonesian National Army Level II Hospitals. International Journal of Business and Management Invention ISSN, 5(5), 30-44. Retrieved from www.ijbmi.org

Budiaji, W. (2013). Skala Pengukuran dan Jumlah Respon Skala Likert. Jurnal Ilmu Pertanian Dan Perikanan.

Damanik, D., \& Wibowo, F. S. (2018). Implementasi Strategi 4P Dalam Meningkatkan Frekuensi Public Event Di Harris Hotel and Conventions Bekasi (Hhcb). National Conference of Creative Industry, (September), 5-6. https://doi.org/10.30813/ncci.v0i0.1248

Fund, I. M. (2019). Publikasi World Economic Outlook Database ,. International Monetary Fund.

Gürbilek, N. (2013). Definisi Operasional Variabel. Journal of Chemical Information and Modeling. https://doi.org/10.1017/CBO9781107415324.004

Hariyono, P. A., Laely, N., \& Prastiti, E. (2019). Analisis Pengaruh Variabel Kualitas Pelayanan Terhadap Kepuasan Pelanggan Pada Kedai Ice Cream Gubuk Bambu Kab. Kediri. JIMEK: Jurnal Ilmiah Mahasiswa Ekonomi, 1(2), 189. https://doi.org/10.30737/jimek.v1i2.314

Heryana, A. (2015). Kerangka Teori, Kerangka Konsep, Variabel Penelitian, Dan Hipotesis Penelitian (Dalam Penelitian Kuantitatif). Metodologi Penelitian.

Hidayat, A. (2017). Cara Hitung Rumus Slovin Besar Sampel.

Hill, N., \& Alexander, J. (2017). The Handbook of Customer Satisfaction and Loyalty Measurement (3rd ed.). https://doi.org/https://doi.org/10.4324/9781315239279

Indonesia, B. (2018). Publikasi Laporan Perekonomian Indonesia. Bank Indonesia.

Kelana Putera, A., \& Wahyono. (2018). Pengaruh Kualitas Pelayanan, Citra Merek, dan Kualitas Produk Terhadap Loyalitas Konsumen melalui Kepuasan Konsumen. Management Analysis Journal, 7(1). Retrieved from http://maj.unnes.ac.id

Komari, A., Laely, N., \& Panjaitan, H. (2017). Marketing Performance Analysis by Customer Relationship Marketing , Market Orientation, and The Image of Islamic Banks in Kediri , East Java , Indonesia. 6(3), 1-9.

Lovelock, C. (2012). Manajemen Pemasaran Jasa : Manusia, Teknologi, Strategi : Perspektif Indonesia. Jakarta : Erlangga. 
Maksum, A. (2012). Data, Teknik Pengumpulan Data dan Instrumen Penelitian. Jurnal Cakrawala Kependidikan, (agustus), 107.

Nurlaely, Sularso, A., \& Panjaitan, H. (2019). Influence of Customer Relationship Management and Product Innovation on Market Orientation, Competitive Advantage in Improving the Marketing Performance of Food Industry Small Businesses In East Java. International Journal of Business and Management Invention (IJBMI), 8(04), 13.

Panjaitan, H., \& Djunaedi. (2017). Product Advantage , Customer Relationship Marketing , and Service Quality on Customer Satisfaction of Bank Syariah Mandiri in Surabaya. International Review of Management and Marketing, 7(4), 122-130.

Philip, K., \& Armstrong, G. (2010). Principles of Marketing (9th ed.). USA: Prentice Hall.

Purnamasari, Y., \& Madiawati, P. N. (2014). Pengaruh Kualitas Pelayanan Terhadap Kepuasan Konsumen Yang Berdampak Pada Loyalitas Konsumen Di Mcdonald's Cabang Cibubur Jakarta. Jurnal Studi Manajemen Dan Bisnis, 1(2), 27-36.

Putra, Y. P., Safi'i, I., \& Ruhamak, D. (2017). Pengaruh E-Service Quality terhadap E-Loyalty melalui E-Satisfaction pada Pengguna E-Banking di Kota Kediri. Senima, 3(Senima 3), 432-440.

Putranto, R. R., Utami, S., \& Nurbambang, R. (2019). Pengaruh Kualitas Pelayanan Terhadap Kepuasan Konsumen (Studi Kasus Pada Jasa Servis Ahass Rizky Motor Prambon Nganjuk). JIMEK : Jurnal Ilmiah Mahasiswa Ekonomi, 2, 182-197.

Sugiyono. (2014). Teknik Pengumpulan Data. Metode Penelitian Kuantitatif, Kualitatif Dan $R \& D, 137$. https://doi.org/10.3354/dao02420

Tjiptono, F., \& Tjiptono, F. (2012). Service management: mewujudkan layanan prima / Fandy Tjiptono. ,Service Management: Mewujudkan Layanan Prima / Fandy Tjiptono. https://doi.org/10.1519/JPT.0b013e31826e7d33

Tumbuan, W., Mandey, S., \& Kakasih, S. (2014). Produk, Harga, Promosi, Dan Filosofi Terhadap Loyalitas Konsumen Meubel Bambu Batik Tekun Jaya Di Kabupaten Kepulauan Sangihe. Jurnal Riset Ekonomi, Manajemen, Bisnis Dan Akuntansi, 2(3), 379388.

Vina Mandasari. (2012). Analisis Pengaruh Kualitas Pelayanan, Kepuasan Pelanggan, Dan Nilai Pelanggan Dalam Meningkatkan Loyalitas Pelanggan Joglosemar Bus. Universitas Diponegoro.

W, R. S., Utami, S., \& Rochani, S. (2018). Pengaruh Harga Dan Kualitas Pelayanan Terhadap Kepuasan Konsumen Pada Alfamart J1. Jaksa Agung Suprapto No.11 Mojoroto - Kediri. JIMEK : Jurnal Ilmiah Mahasiswa Ekonomi, 1(11), 285-298.

Whidmurni. (2017). Penelitian Kuantitatif. Pemaparan Metodenpenelitian Kuantitatif.

Widjoyo, I. O., Rumambi, L. J., \& Kunto, Y. S. (2013). Analisa Pengaruh Kualitas Layanan terhadap Kepuasan Konsumen pada Layanan Drive Thru McDonald's Basuki Rahmat di Surabaya. Jurnal Manajemen Pem, 1(1), 1-12.

Yusup, F. (2018). Uji Validitas dan Reliabilitas Instrumen Penelitian Kuantitatif. Jurnal Tarbiyah : Jurnal Ilmiah Kependidikan. https://doi.org/10.18592/tarbiyah.v7i1.2100

Zeithaml, V. A. (2010). Delivering Quality Service. Retrieved from https://books.google.co.id/books?id=kyvhCLoVmHgC 